\title{
Functional GluR6 Kainate Receptors in the Striatum: Indirect Downregulation of Synaptic Transmission
}

\author{
Karima Chergui, Alexandre Bouron, Elisabeth Normand, and Christophe Mulle \\ Centre National de la Recherche Scientifique, Unite Mixte Recherche 5091, Université Victor Segalen-Bordeaux II, 33076 \\ Bordeaux Cedex, France
}

Kainate receptors (KARs) are abundantly expressed in the basal ganglia, but their function in synaptic transmission has not been established. In the present study, we show that the GluR6 subunit of KARs is expressed in both substance $P$ - and enkephalin-containing GABAergic projection neurons of the mouse striatum. Using whole-cell voltage-clamp recordings in brain slices, we demonstrate the presence of functional KARs in the dorsal striatum activated by low concentrations of the AMPA/KAR agonist domoate in wild-type but not GluR6deficient mice. Despite the abundance of KARs, we found no evidence for synaptic activation of these receptors after single or repetitive stimulation of glutamatergic afferents. Domoate induces a transient increase in the frequency of spontaneous IPSCs of small amplitude and a sustained depression of large IPSCs evoked by minimal electrical stimulation within the striatum in wild-type mice but not in GluR6-deficient mice. This depressant effect is inhibited in presence of adenosine $A_{2 A}$ receptor antagonists, ZM-241385 and $\mathrm{SCH}-58261$. These data strongly suggest that, in striatal neurons, KARs depress GABAergic synaptic transmission indirectly via release of adenosine acting on $A_{2 A}$ receptors.

Key words: GluR6; kainate receptors; glutamate; IPSC; adenosine $A_{2 A}$ receptor; mouse
The principal excitatory neurotransmitter in the brain, glutamate, mediates fast synaptic transmission through three classes of ionotropic receptors: NMDA, AMPA, and kainate receptors (KARs). KARs are composed of five subunits: GluR5, GluR6, GluR7, KA1, and KA2 (Bettler and Mulle, 1995; Chittajalu et al., 1999). GluR5, GluR6, and GluR7 subunits form functional homomeric receptors or heteromeric receptors when combined with KA1 or KA2. Until recently, the lack of specific pharmacological tools discriminating kainate from AMPA receptors did not permit elucidation of the function of KARs in the CNS. The use of the noncompetitive AMPA receptor antagonist GYKI 53655 has enabled the separation of kainate- and AMPA-receptor mediated responses (Lerma et al., 1997; Bleakman and Lodge, 1998; Chittajalu et al., 1999) and has allowed the demonstration of a physiological role for KARs both in synaptic transmission and in its modulation. KARs can be synaptically activated in the hippocampus, retina, dorsal horn neurons of the spinal cord, neocortex, and amygdala with single-pulse or high-frequency stimulation of glutamatergic fibers (Castillo et al., 1997; Vignes and Collingridge, 1997; Cossart et al., 1998; Frerking et al., 1998; Li and Rogawski, 1998; Mulle et al., 1998; DeVries and Schwartz, 1999; Kidd and Isaac, 1999; Li et al., 1999) In addition, activation of KARs downregulate both glutamatergic and GABAergic transmission

\footnotetext{
Received Oct. 25, 1999; revised Dec. 30, 1999; accepted Jan. 5, 2000.

This work was supported by grants and fellowships of the Centre National de la Recherche Scientifique, the French Ministery of Education, the Fondation pour la Recherche Médicale (to C.M. and A.B.), and the Région Aquitaine. K.C. was supported by a fellowship from the Swedish Foundation for Medical Research. We thank Steve Heinemann for allowing us the use of GluR6-deficient mice.

Correspondence should be addressed to Christophe Mulle, Centre National de la Recherche Scientifique, Unite Mixte Recherche 5091, Université Victor SegalenBordeaux II, 146 rue Léo-Saignat, 33076 Bordeaux Cedex, France. E-mail: mulle@u-bordeaux2.fr.

Dr. Chergui's present address: The Rockefeller University, Laboratory of Molecular and Cellular Neuroscience, 1230 York Avenue, New York, NY 10021.

Copyright (C) 2000 Society for Neuroscience $0270-6474 / 00 / 202175-08 \$ 15.00 / 0$
}

in the hippocampus by a mechanism that might involve presynaptic KARs, although this notion is currently debated (Chittajallu et al., 1996; Rodriguez-Moreno et al., 1997; Cossart et al., 1998; Frerking et al., 1998; Kamiya and Ozawa, 1998; RodriguezMoreno and Lerma, 1998; Bureau et al., 1999). Recently, the analysis of a mutant mice knock-out of the GluR6 gene has made it possible to demonstrate a pivotal role for this subunit in the composition of functional high-affinity KARs responsible for high susceptibility to kainate excitotoxicity in CA3 neurons (Mulle et al., 1998).

The role for KARs in either synaptic transmission, synaptic plasticity, or in glutamate-induced neuronal degeneration in basal ganglia, where KARs are expressed at relatively high levels (Bischoff et al., 1997) has not been addressed. The aim of the present study was to determine whether KARs play a direct role in synaptic transmission in the dorsal striatum and/or in its modulation. Because striatal neurons mainly express the GluR6 subunit (Bischoff et al., 1997), we have used GluR6-deficient mice as a tool for investigating the functional role of KARs. Here, we demonstrate the presence of functional KARs in the striatum that do not appear to participate directly in glutamatergic synaptic transmission but rather, in the modulation of GABAergic transmission. We show that this modulation is likely to involve release of adenosine and activation of adenosine $A_{2 \mathrm{~A}}$ receptors.

\section{MATERIALS AND METHODS}

In situ hybridization. Double in situ hybridization was performed as described by Svenningsson et al. (1997) on 10- $\mu \mathrm{m}$-thick brain sections of wild-type mice from an hybrid C57BL/6x129Sv strain. The GluR6 cRNA probe was labeled with $\left[{ }^{35} \mathrm{~S}\right] \mathrm{UTP}$, whereas probes for substance $\mathrm{P}$ and enkephalin mRNA were labeled with digoxigenin-11-UTP. Brain sections were hybridized overnight with a combination of ${ }^{35} \mathrm{~S}-$ and digoxigenin-labeled probes. Slides were washed in RNaseA and various concentrations of SSC. Sections were rinsed in buffer and incubated with alkaline phosphatase-conjugated anti-digoxigenin antiserum. After a series of rinses and incubation in different buffers, sections were dried and 
dipped into Ilford K5 emulsion. The sections were exposed for 3 weeks then developed and mounted for microscopic examination. Labeled neurons in the dorsal and ventral striatum were identified and counted by using computer-assisted image analysis (Histo 200; Biocom, Les Ulis, France). Two categories of neurons were counted: those exhibiting either only nonradioactive signal or only radioactive signal and those that exhibited both signals. Data are analyzed as neuronal density (number of neurons counted per square millimeter).

Electrophysiology. Parasagittal brain slices (350- to 400- $\mu$ m-thick) were made from hybrid C57BL/6x129Sv wild-type and GluR6-deficient mice (Mulle et al., 1998) aged $15-23$ d. Slices were kept at $32^{\circ} \mathrm{C}$ in an oxygenated $\left(95 \% \mathrm{O}_{2}\right.$ and $\left.5 \% \mathrm{O}_{2}\right)$ artificial CSF (ACSF) containing (in mM): $125 \mathrm{NaCl}, 2.5 \mathrm{KCl}, 2 \mathrm{CaCl}_{2}, 1 \mathrm{MgCl}_{2}, 1.25 \mathrm{NaH}_{2} \mathrm{PO}_{4}, 26 \mathrm{NaHCO}_{3}$, and 25 glucose, $\mathrm{pH}$ 7.4. Slices were transferred to a recording chamber where they were continuously perfused with oxygenated ACSF. Neurons were visualized throughout the experiment with an upright microscope using Nomarski-type differential interference contrast optics combined with infrared videomicroscopy. Whole-cell voltage-clamp recordings of medium-sized neurons in the dorsal striatum were made at room temperature with patch electrodes pulled from borosilicate glass capillaries and filled with a CsCl-based solution containing (in $\mathrm{mM}$ ): $140 \mathrm{CsCl}, 2$ $\mathrm{MgCl}_{2}, 1 \mathrm{CaCl}_{2}, 10$ EGTA, 10 HEPES, and $2 \mathrm{Na}_{2}$-ATP, pH 7.3. Electrode resistance was 2.6-3.2 M . Whole-cell membrane currents were recorded with an EPC9 amplifier (Heka, Lambrecht, Germany) driven by a Macintosh PowerPC computer. Neurons were voltageclamped at a holding potential of $-80 \mathrm{mV}$. For cell-attached recordings, the patch pipette was filled with a HEPES-buffered extracellular solution. For whole-cell current-clamp experiments, patch pipettes were filled with a solution containing (in $\mathrm{mM}$ ): $120 \mathrm{KGluconate,} 20 \mathrm{KCl}, 2$ $\mathrm{MgCl}_{2}, 1 \mathrm{CaCl}_{2}, 10$ EGTA, 10 HEPES, and $2 \mathrm{Na}_{2}$-ATP, pH 7.3.

EPSCs or IPSCs were evoked at a frequency of $0.2 \mathrm{~Hz}$ by electrical stimulation of the slice using a patch electrode filled with saline positioned on the slice surface in the vicinity of the recorded neuron. To study evoked EPSCs and IPSCs, the concentrations of $\mathrm{CaCl}_{2}$ and $\mathrm{MgCl}_{2}$ were both increased to $4 \mathrm{~mm}$. Miniature IPSCs (mIPSCs) were recorded in presence of TTX (400 nM) with $3 \mathrm{~mm} \mathrm{CaCl}_{2}$. DL-AP5 $(50 \mu \mathrm{M})$ was present throughout all recordings. Data were acquired using "Pulse" program (Heka) and analyzed using macros written for Igor (Wavemetrix) and Detectivent for analysis of mIPSC (Bureau et al., 1999). When appropriate, the statistical significance of the results was assessed by using Student's $t$ test. Numerical values are expressed as mean \pm SEM, with $n$ indicating the number of cells tested.

All drugs were applied in the perfusing solution. Tetrodotoxin (TTX), DL-AP5, NBQX, CNQX, and picrotoxin were obtained from Sigma (St. Louis, MO). Domoate and ZM 241385 were purchased from Tocris Cookson (Bristol, UK). GYKI 53655 and LY303070 were a generous gift from Eli Lilly and Co. (Indianapolis, IN). SCH-58261 was a generous gift from Dr. Ongini (Schering-Plough).

\section{RESULTS}

\section{Cellular distribution of GluR6 mRNA in the dorsal striatum}

Neurons that constitute the striatum are, for up to $95 \%$, medium spiny projection neurons that contain GABA as their main neurotransmitter (for review, see Gerfen and Wilson, 1996). They are divided into two subpopulations depending on neuropeptides they coexpress with GABA, i.e., either substance P (SP) or enkephalin and their projection targets, substantia nigra and globus pallidus, respectively. We examined whether the GluR6 subunit was expressed in one or both of these two neuronal subpopulations. For this purpose, we performed double in situ hybridization, on the same brain section, for GluR6 mRNA (radioactive probe) and either enkephalin or substance P mRNA (digoxigenin-labeled probe). We observed that $60 \%$ of neurons expressing GluR6 mRNA also expressed SP mRNA, whereas $48 \%$ of neurons expressing GluR6 mRNA also express enkephalin mRNA (Fig. 1). Given the known distribution of SPcontaining versus enkephalin-containing medium spiny neurons in the striatum ( $\sim 50 \%$ for each), our data are consistent with an

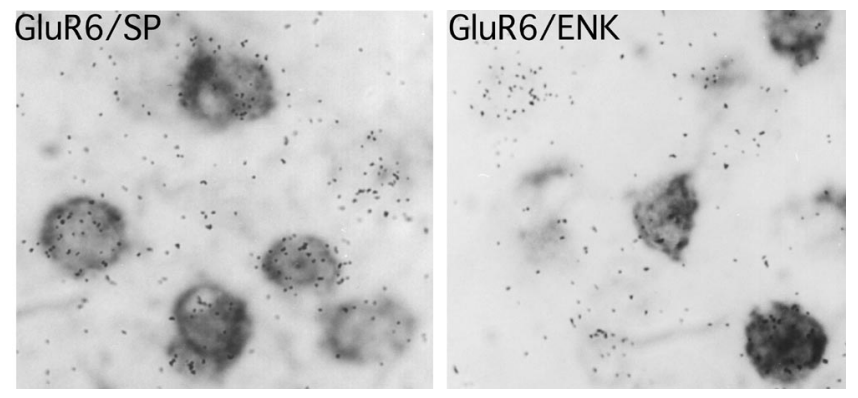

Figure 1. Cellular localization of GluR6 mRNA in the dorsal striatum. Emulsion autoradiograms from double in situ hybridization experiments showing the colocalization of GluR6 mRNA (radioactive probe, silver grains) with substance P (SP) or enkephalin (ENK) mRNA (digoxigeninlabeled probe, brown labeling) in the dorsal striatum of a wild-type mouse. The majority of substance P- and enkephalin-containing neurons coexpress GluR6 mRNA.

expression of GluR6 in both populations of medium spiny neurons.

\section{Functional KARs assembled with the GluR6 subunit in the striatum}

We measured, in the whole-cell configuration, the amplitude of inward currents evoked by bath application of domoate, an AMPA/KAR agonist, in the presence of DL-AP5 $(50 \mu \mathrm{M})$, picrotoxin $(100 \mu \mathrm{M})$, and tetrodotoxin (TTX) (400 nM). In striatal neurons recorded from wild-type mice, domoate (applied for 2 min) evoked an inward current at concentrations as low as $200 \mathrm{~nm}$ (Fig. $2 B$ ). The amplitude of currents activated by $500 \mathrm{~nm}$ domoate was, on average, $380.6 \pm 65.4 \mathrm{pA}(n=11)$. In GluR6-deficient mice, low concentrations of domoate (200-500 nM) hardly activated any current $(15.6 \pm 9.4$ pA for $500 \mathrm{~nm}$ domoate, $n=4$, Fig. 2 ). The concentration required to evoke an inward current in neurons from GluR6-deficient mice was increased to 1-5 $\mu \mathrm{M}$ (Figs. 2, 3). Dose-response curves showed a higher sensitivity to domoate for striatal neurons recorded in wild-type mice as compared to GluR6-deficient mice (Fig. 2B). At all concentrations of domoate tested, the difference in the amplitude of inward currents between wild-type and GluR6 -/- mice was significant with $p<0.01$.

NBQX, a competitive antagonist at both AMPARs and KARs, was shown to be more potent on AMPARs than on KARs in hippocampal CA1 neurons in the slice preparation (Bureau et al., 1999). Accordingly, NBQX (1 $\mu \mathrm{M})$ did not affect the amplitude of currents evoked in wild-type mice by low concentrations of domoate (500 nM, Fig. 3). Bath application of GYKI $53655(50 \mu \mathrm{M})$, a selective AMPAR antagonist (Paternain et al., 1995), in the presence of NBQX $(1 \mu \mathrm{M})$ did not affect this current either (Fig. $3 B)$. The amplitude of currents evoked by $1 \mu \mathrm{M}$ domoate was decreased in the presence of NBQX $(1 \mu \mathrm{M})$, suggesting that AMPARs are also activated at this and higher concentrations of domoate. In GluR6-deficient mice, inward currents evoked by domoate ( 2 and $5 \mu \mathrm{M}$ ) were totally blocked by NBQX (1 $\mu \mathrm{M}$, Fig. 3 ), indicating that domoate only evokes AMPAR-mediated currents in these mice. These results demonstrate the presence of functional KARs assembled with the GluR6 subunit in the striatum that can be activated by low concentrations of domoate.

We tested whether KAR-activated inward currents were sufficient to trigger action potential firing in medium spiny neurons. Action potentials were recorded extracellularly in the cellattached mode, which prevents any perturbation of the intracel- 


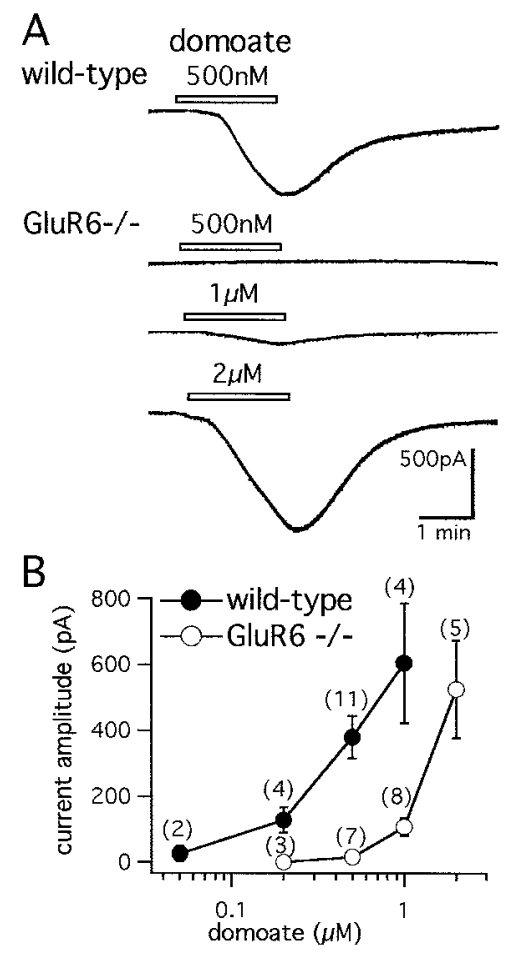

Figure 2. Functional GluR6 KARs in the mouse striatum. A, Inward current evoked by $500 \mathrm{~nm}$ domoate in a neuron recorded from the dorsal striatum of a wild-type mouse, in the presence of TTX (500 nM), DL-AP5 $(50 \mu \mathrm{M})$, and picrotoxin $(100 \mu \mathrm{M})$. In GluR6-deficient mice (GluR6-/-), higher concentrations of domoate are needed to activate an inward current in striatal neurons. $B$, Dose-response curves for low concentrations of domoate in the striatum of wild-type and GluR6-deficient mice. The amplitude of the inward current evoked by each concentration of domoate is represented in the $y$-axis (mean \pm SEM, $n=3-11$ ).

lular milieu. Under control conditions, with $4 \mathrm{mM} \mathrm{Ca}^{2+}$ and $4 \mathrm{~mm}$ $\mathrm{Mg}^{2+}$ in the extracellular medium, striatal neurons were completely silent $(n=8)$. Bath application of domoate $(500 \mathrm{~nm})$ triggered a transient discharge of action potentials that stopped before the end of the application of the agonist (Fig. 4). In four cells, a rebound of spike activity was observed during washing of the agonist. The frequency of spike firing reached, on average, a maximum of $4.8 \mathrm{~Hz}$ (range, $1-18 \mathrm{~Hz}, n=8$ ). In whole-cell current-clamp recordings, domoate depolarized the neuronal membrane by an average of $28 \pm 6 \mathrm{mV}(n=5)$ and $32 \pm 7 \mathrm{mV}$ $(n=9)$ at a concentration of 200 and $500 \mathrm{~nm}$, respectively. The depolarization resulted in repetitive action potential firing (Fig. $4 B$ ). In spite of a sustained depolarization, spike discharge displayed a marked accommodation, consistent with the transient discharge observed in the cell-attached mode. We found however that domoate did not affect the threshold for action potential triggered by a depolarizing pulse during the accommodation period (data not shown).

\section{KARs are not involved in glutamatergic synaptic transmission}

Stimulation of glutamatergic afferent fibers by single pulse stimulations of the slice in the vicinity of the recorded neuron evoked EPSCs in the presence of bicuculline $(20 \mu \mathrm{M})$ or picrotoxin $(100$ $\mu \mathrm{M})$ and DL-AP5 (100 $\mu \mathrm{M})$ (Fig. 5). These EPSCs were mainly mediated by AMPARs because they were largely inhibited by GYKI $53655(50 \mu \mathrm{M})(n=4$ cells $)$ or its active isomer of GYKI 53655, LY303070 (25 $\mu \mathrm{M})(n=5$ cells), in wild-type mice (Fig. 5).

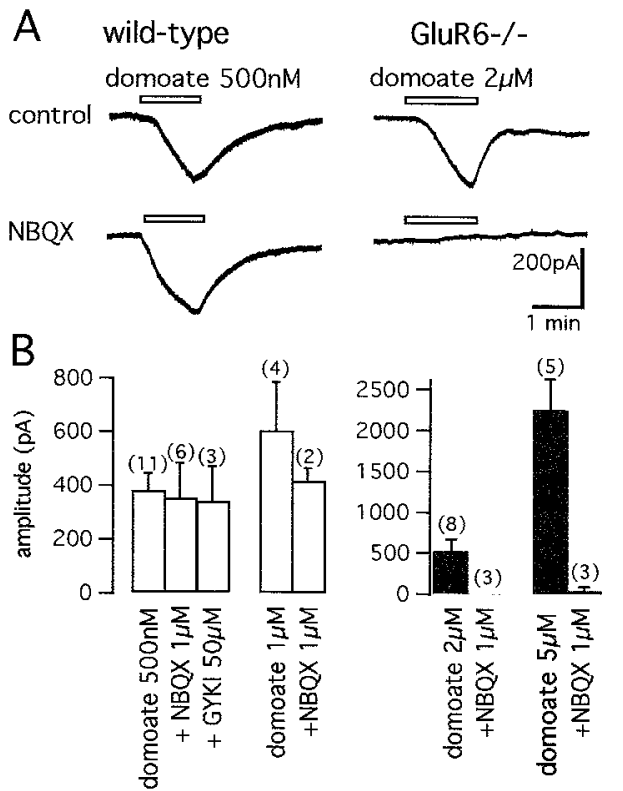

Figure 3. Inward currents activated by low concentrations of domoate are mediated by KARs. $A$, In wild-type mice (left traces), the inward current activated by domoate $(500 \mathrm{nM})$ was unaffected by low concentrations of NBQX $(1 \mu \mathrm{M})$. In GluR6-deficient mice (right traces), the inward current activated by a larger concentration of domoate was totally blocked by NBQX $(1 \mu \mathrm{M})$. B, Mean amplitude of inward currents activated by domoate $(500 \mathrm{nM}, 1,2$, or $5 \mu \mathrm{M})$ alone or in the presence of NBQX $(1 \mu \mathrm{M})$ or NBQX $(1 \mu \mathrm{M})+$ GYKI $53655(50 \mu \mathrm{M})($ mean $\pm \mathrm{SEM}, n=3-11)$.

In the presence of these AMPAR antagonists, a single stimulation or a train of five stimulations ( $5 \mathrm{msec}$ interval) evoked a slowly decaying postsynaptic current (PSC) of small amplitude ( $<10 \mathrm{pA}$ for a single stimulation) in wild-type mice (Fig. 5). These GYKI-resistant PSCs recorded in striatal neurons are probably not caused by synaptic activation of KARs because the AMPA/KAR antagonist CNQX $(50 \mu \mathrm{M})$ failed to block these PSCs $(n=4$ cells) (Fig. $5 B)$. In addition, in the presence of bicuculline and APV, PSCs resistant to LY $303070(25 \mu \mathrm{M})$ and CNQX $(50 \mu \mathrm{M})$ could also be evoked in striatal neurons from GluR6-deficient mice (Fig. 5) ( $n=3$ cells).

\section{Modulation of GABAergic synaptic transmission by GluR6-containing KARs}

We studied the possibility that KARs could modulate GABAergic transmission in the striatum, as shown in the area CA1 of the hippocampus (Rodriguez-Moreno et al., 1997; Cossart et al., 1998; Frerking et al., 1998; Bureau et al., 1999). GABAergic innervation of the striatum arises both from axon collaterals of projection neurons and from GABAergic interneurons. Because activation of KARs causes high-frequency firing in medium spiny neurons, we tested the effects of domoate (200 and $500 \mathrm{nM})$ on the occurrence of spontaneous IPSCs (sIPSCs). Bath application of domoate in the presence of NBQX $(1 \mu \mathrm{M})$ or GYKI 53655 (50 $\mu \mathrm{M})$ and DL-AP5 $(50 \mu \mathrm{M})$ to block AMPA and NMDA receptors markedly increased the frequency of sIPSCs (Fig. 6), from $2.1 \pm$ $0.4 \mathrm{~Hz}$ in control conditions to $16.0 \pm 3.1 \mathrm{~Hz}$ during domoate (500 nM) application ( $n=8$ cells; $p<0.01$; paired $t$ test). The frequency of sIPSC often decreased to baseline levels before the end of the application of domoate and before the inward current returned to baseline (Fig. 6). The mean amplitude of sIPSCs recorded in the presence of domoate $(500 \mathrm{nM})(41.6 \pm 5.5 \mathrm{pA}$; $n=8$ ) was of comparable amplitude to that of sIPSCs recorded 

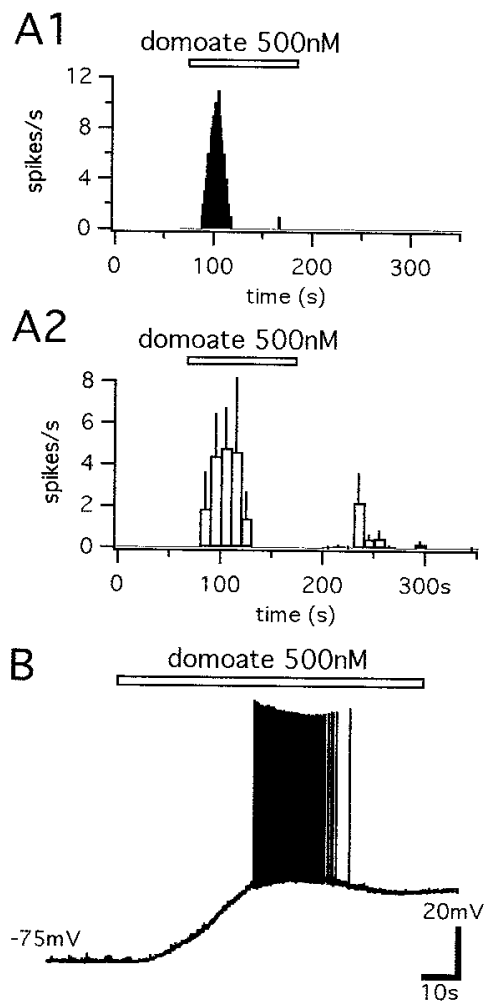

Figure 4. Domoate in the presence of NBQX $(1 \mu \mathrm{M})$ and DL-AP5 (50 $\mu \mathrm{M})$ causes depolarization and transiently triggers action potential firing in striatal neurons. $A 1$, Cell-attached recording of a medium-sized striatal neuron in the presence of NBQX $(1 \mu \mathrm{M})$. In control conditions, this neuron did not discharge spontaneous action potentials. Domoate $(500$ $\mathrm{nM}, 2 \mathrm{~min}$ ) triggered action potential firing (up to a frequency of $11 \mathrm{~Hz}$ ) that stopped before the end of agonist application. A2, Histogram of the average increase in spike frequency induced by domoate $(n=8$ cells). $B$, Whole-cell current-clamp recording of a medium-size striatal neuron. An intracellular solution containing K-Gluconate (120 mM) and $\mathrm{KCl}(20 \mathrm{mM})$ was used. In the presence of NBQX $(1 \mu \mathrm{M})$, domoate depolarizes the neuronal membrane by $>30 \mathrm{mV}$ and triggers action potential discharge. Despite sustained depolarization, action potential firing stops before the end of domoate application.

in control conditions $(39.6 \pm 4.4 \mathrm{pA} ; n=8 ; p=0.3)$. Occasionally, domoate evoked a small number of sIPSCs of larger amplitude $(>200 \mathrm{pA})$ that were generally not encountered in control conditions and that represented on average $1.1 \pm 0.4 \%$ of all sIPSCs in the presence of domoate.

We then tested the effects of KAR activation on the amplitude of evoked IPSCs (eIPSCs). Electrical stimulation of the slice in the vicinity of the recorded neuron, in the presence of NBQX (1 $\mu \mathrm{M})$ or GYKI $53655(50 \mu \mathrm{M})$ and DL-AP5 $(50 \mu \mathrm{M})$, elicited GABAergic IPSCs that were fully blocked by picrotoxin (100 $\mu \mathrm{M})$. By adjusting stimulation intensity near threshold, failures to synaptic transmission could be observed in a number of neurons. The sharp increase in failure rate when decreasing stimulation intensity as well as the all or none type of response suggested that under these conditions, only one or a few presynaptic fibers were stimulated. In all neurons tested, it was clear that under these conditions of minimal stimulation, eIPSCs displayed larger amplitudes than spontaneous IPSCs recorded either in control conditions or in the presence of domoate. The distribution of the amplitudes of IPSCs evoked by minimal stimulation (i.e., close to stimulation threshold, with significant numbers of failures) could

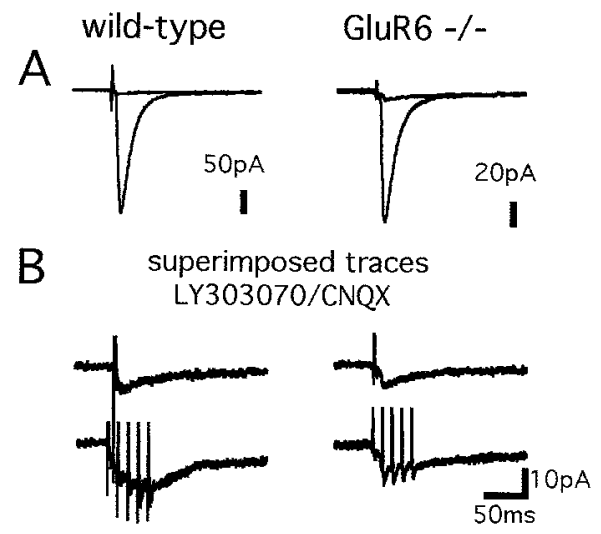

Figure 5. KARs do not participate in EPSCs. $A$, In wild-type mice, EPSPs evoked by single pulse intrastriatal stimulation in the presence of bicuculline $(20 \mu \mathrm{M})$ and DL-AP5 $(100 \mu \mathrm{M})$ were largely blocked by the AMPA receptor antagonist LY $303070(25 \mu \mathrm{M})$ in wild-type mice (left traces) as well as in GluR6 -/- mice (right traces). B, CNQX $(50 \mu \mathrm{M})$ does not block small LY 303070-resistant synaptic currents. Traces of evoked synaptic currents recorded in the presence of LY 303070 and in the presence of CNQX $(50 \mu \mathrm{M})$ are superimposed, showing no difference in PSC amplitude or time course in the presence of these two antagonists. In the bottom traces, train stimulation (five pulses, $5 \mathrm{msec}$ interval) evoked slowly decaying postsynaptic currents. No difference in the pharmacology of EPSCs was observed in GluR6-deficient mice (right traces) as compared to wild-type mice. Average of 20 sweeps for each trace in $A$ and $B$.

generally be fitted by a single Gaussian with an average peak value of $425 \mathrm{pA}$ (range, $125-1160 \mathrm{pA} ; n=18$ ).

Bath application of domoate (200 and $500 \mathrm{~nm}$ for $2 \mathrm{~min}$ ) decreased the amplitude of eIPSCs (Fig. 7; see Fig. 9 for $500 \mathrm{~nm}$ domoate). The mean eIPSC amplitude decreased to $41.2 \pm 7.3 \%$ $(n=13 ; p<0.0001 ;$ paired $t$ test $)$ and to $38.2 \pm 5.7 \%(n=18 ; p<$ 0.0001 ; paired $t$ test) of control values after application of domoate at a concentration of 200 and $500 \mathrm{~nm}$, respectively. This decrease was accompanied in some neurons (five cells) with an increase in the number of failures. On average, failure rate increased by $20 \pm 7 \%(n=13)$, for $200 \mathrm{~nm}$ domoate. In GluR6deficient mice however, domoate ( $200 \mathrm{~nm}$ for $2 \mathrm{~min}$ ) did not affect the amplitude of IPSCs evoked by intrastriatal stimulation (Fig. 7) and did not increase the number of failures in the seven neurons examined.

We examined the effects of domoate on the frequency and amplitude of mIPSCs in the presence of TTX (400 nM), DL-AP5 $(50 \mu \mathrm{M})$, and NBQX $(1 \mu \mathrm{M})$. In control conditions, mIPSC frequency ranged from 0.2 to $2.2 \mathrm{~Hz}$ (average, $1.3 \mathrm{~Hz}$ ), and mean mIPSC amplitude ranged from 20 to $59 \mathrm{pA}$ (average, $38.7 \mathrm{pA}$; $n=8$ cells). In the majority of cells examined (six of eight cells), domoate ( $500 \mathrm{nM}$, for $2 \mathrm{~min})$ induced a moderate decrease (23 \pm $5 \% ; n=6 ; p<0.05$, paired $t$ test) in the frequency of mIPSCs (Fig. 8). The mean mIPSC amplitude also decreased by $15 \%$ $( \pm 5 \% ; n=6 ; p<0.05$; paired $t$ test). As illustrated in the histograms in Figure 8, the decrease in mIPSC amplitude was not caused by a shift in the amplitude of all mIPSCs to smaller values. Instead, it was mainly attributable to a marked depression in the frequency of mIPSCs of larger amplitude, thus reducing the average amplitude of mIPSCs (Fig. 8). These data are in favor of a presynaptic effect of KAR activation on a subclass of mIPSCs.

Adenosine $A_{2 A}$ receptors involvement in the depressant action of domoate on evoked responses

We investigated further the mechanism by which domoate depresses GABAergic transmission in the striatum. One possible 

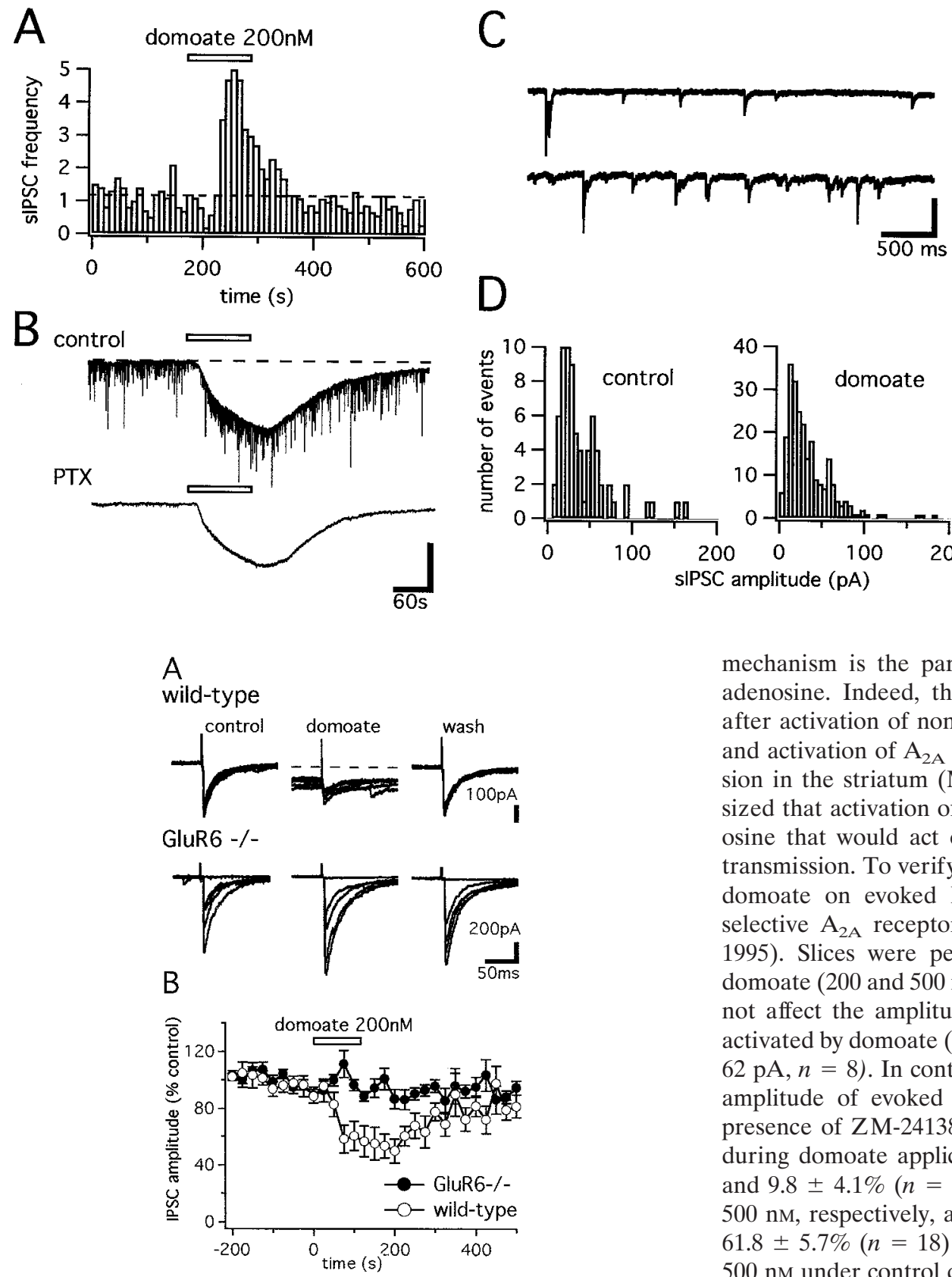

Figure 7. Domoate depresses evoked IPSCs. $A$, IPSCs evoked by minimal intrastriatal stimulation were reversibly depressed by bath application of domoate ( $200 \mathrm{nM}, 2 \mathrm{~min}$ ) in wild-type mice but not in GluR6deficient mice. For each set of traces, five sweeps are superimposed. Top trace, Example of a striatal neuron recorded in a wild-type mouse for which no failure was observed and where the average amplitude of the evoked IPSCs was decreased by domoate. The dotted line represents the level of the control holding current. Bottom traces, Example of a neuron recorded in a GluR6-deficient mouse; domoate (200 nM) did not depress the amplitude of the IPSC and did not increase the number of failures. $B$, Time course of the effect of domoate ( $200 \mathrm{~nm}$ for $2 \mathrm{~min}$ ) on the IPSC amplitude in wild-type mice $(n=13)$ and in GluR6-deficient mice $(n=$ 7). Each point represents the mean ( \pm SEM) IPSC amplitude expressed as percentage of baseline amplitude calculated, for each cell, before domoate application.
Figure 6. Activation of KARs increases the frequency of spontaneous IPSCs of small amplitude in striatal neurons. $A$, Plot of the frequency of spontaneous IPSCs recorded in the presence of GYKI 53655 $(50 \mu \mathrm{M})$ and DL-AP5 $(50 \mu \mathrm{M})$ in control conditions and in the presence of domoate $200 \mathrm{~nm}(2 \mathrm{~min}) . B$, Traces of recording shown at the same time scale as the histogram in $A$. Top trace, Trace from which plot $A$ was drawn. Bottom trace, Recording in the presence of picrotoxin (PTX, 100 $\mu \mathrm{M}$ ), showing the blockade of spontaneous PSCs by this $\mathrm{GABA}_{\mathrm{A}}$ receptor antagonist. The white box represents the time during which domoate was applied. $C$, Traces of spontaneous IPSCs shown at a larger time scale before (top trace) and during (bottom trace) application of domoate. D, Amplitude histograms of spontaneous IPSCs recorded during the same time period (50 $\mathrm{sec}$ ), in control conditions, and in the presence of domoate (200 $\mathrm{nm})$. No major change in the distribution of IPSC amplitudes was observed except for an increase in the number of events in each bin during domoate application. $A-D$ show data from the same neuron.

mechanism is the participation of a retrograde signal such as adenosine. Indeed, this nucleoside is released in the striatum after activation of non-NMDA receptors (Delaney et al., 1998), and activation of $\mathrm{A}_{2 \mathrm{~A}}$ receptors depresses GABAergic transmission in the striatum (Mori et al., 1996). We therefore hypothesized that activation of KARs could lead to the release of adenosine that would act on $\mathrm{A}_{2 \mathrm{~A}}$ receptors to depress GABAergic transmission. To verify this possibility, we examined the effect of domoate on evoked IPSC amplitude in the presence of the selective $\mathrm{A}_{2 \mathrm{~A}}$ receptor antagonist ZM-241385 (Poucher et al., 1995). Slices were perfused with ZM 241385 (1 $\mu \mathrm{M})$ before domoate (200 and $500 \mathrm{nM}$, for $2 \mathrm{~min}$ ) was applied. ZM-241385 did not affect the amplitude of the KAR-mediated inward current activated by domoate (200 nм, $248 \pm 75 \mathrm{pA}, n=7 ; 500 \mathrm{~nm}, 351 \pm$ $62 \mathrm{pA}, n=8)$. In contrast, the ability of domoate to depress the amplitude of evoked IPSCs was dramatically reduced in the presence of ZM-241385 (Fig. 9). The mean amplitude of IPSC during domoate application decreased by $17.0 \pm 8.3 \%(n=5)$ and $9.8 \pm 4.1 \%(n=7)$ for domoate concentrations of 200 and $500 \mathrm{nM}$, respectively, as compared to $58.8 \pm 7.3 \%(n=13)$ and $61.8 \pm 5.7 \%(n=18)$ for domoate concentrations of $200 \mathrm{M}$ and $500 \mathrm{nM}$ under control conditions. In the presence of ZM-241385, domoate (500 nM, for $2 \mathrm{~min}$ ) did not decrease the frequency and amplitude of mIPSCs $(106 \pm 5 \%$ of control mIPSC frequency and $95 \pm 9 \%$ of mean mIPSC amplitude; $n=5$ cells). The effect of domoate was also inhibited in the presence of SCH-58261 (1 $\mu \mathrm{M}$ ), another selective antagonist of $\mathrm{A}_{2 \mathrm{~A}}$ receptors (Zocchi et al., 1996) (inhibition of eIPSC amplitude by $18.7 \pm 4.2 \%$; $n=6$ with $500 \mathrm{~nm}$ domoate). In agreement with previous results in the rat (Mori et al., 1996), the $\mathrm{A}_{2 \mathrm{~A}}$ receptor agonist CGS-21680 decreased eIPSC amplitude by $25.2 \pm 5.1 \%(n=8 ; p<0.05)$. Finally, preincubation with CGS-21680 $(1 \mu \mathrm{M})$ significantly attenuated the depressant action of domoate $(500 \mathrm{nM})$ on evoked IPSC amplitude (with $p<0.005$ ). Indeed, in the presence of this $\mathrm{A}_{2 \mathrm{~A}}$ agonist, domoate only led to a small nonsignificant decrease in the amplitude of evoked IPSCs, as compared to the IPSC amplitude measured in the presence of CGS-21680 (17 $\pm 7 \% ; n=6$; $p>0.05)$. Altogether, these data strongly suggest an involvement 
Figure 8. Effect of domoate on mIPSC frequency and amplitude in wild-type mice. Miniature IPSCs were recorded in the presence of TTX (400 nM), NBQX (1 $\mu \mathrm{M})$, and APV $(50 \mu \mathrm{M})$. $A$, Plot of mIPSC frequency versus time. The dotted line represents the average control value. Superimposed on the plot is the inward current evoked by activation of somatodendritic KARs present in the recorded neuron. Concomitant with this inward current, domoate (500 $\mathrm{nm}$ for $2 \mathrm{~min}$ ) causes a moderate decrease in total mIPSC frequency. $B-D$, In the same neuron, a closer inspection of the effects of domoate on mIPSCs indicates that domoate mainly affects large-amplitude mIPSCs. $B$, Each mIPSC is represented by a vertical bar proportional to its amplitude to allow visualization of the activity over long recording periods (2 min). $C$, Amplitude distribution histogram of mIPSCs recorded over the same time period ( $3 \mathrm{~min}$ ) in control conditions (open bars) and after application of domoate (filled bars). D, Cumulative amplitude histogram corresponding to the distributions shown in $C$ for control conditions (dashed line) and after application of domoate (solid line).
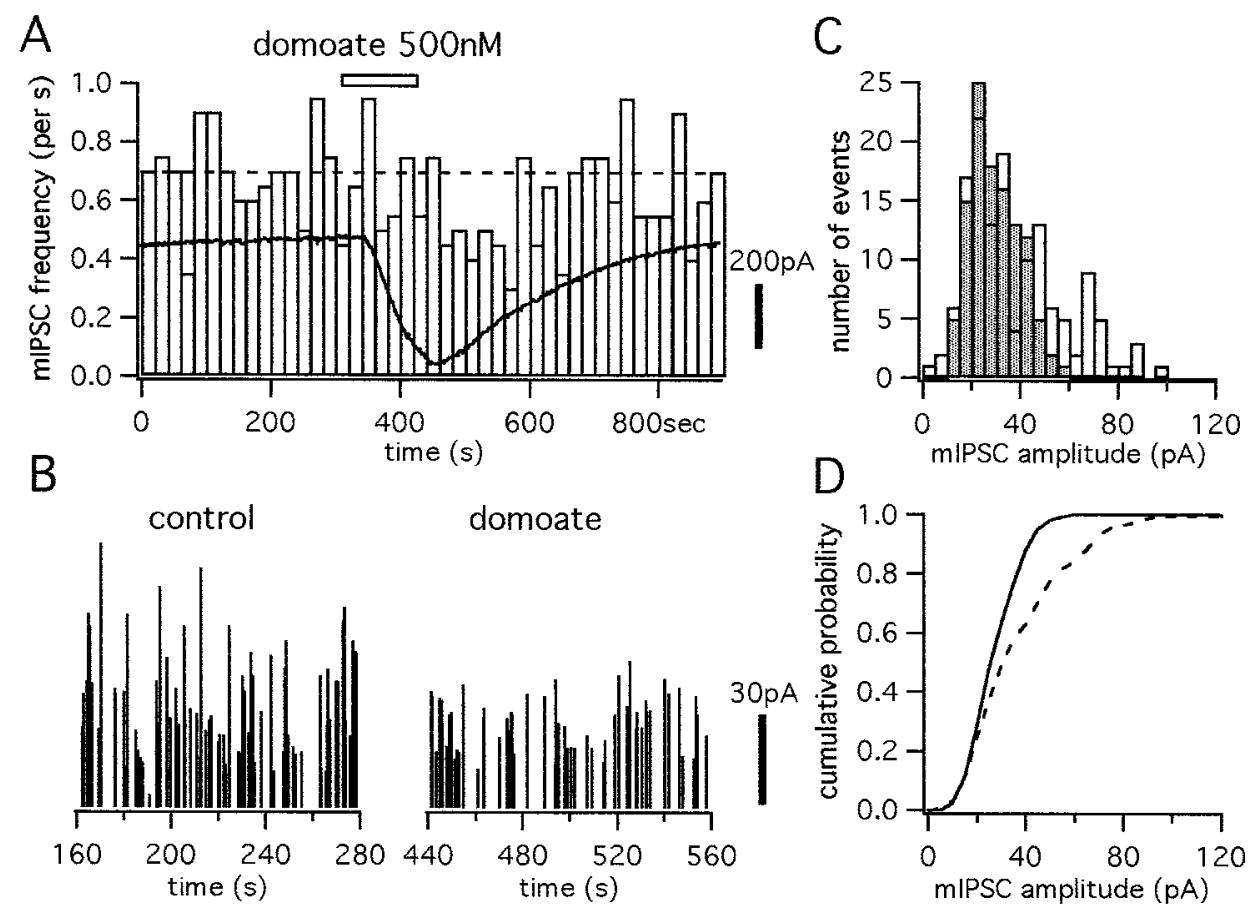

of $\mathrm{A}_{2 \mathrm{~A}}$ receptors in the depressant action of KARs in striatal neurons.

\section{DISCUSSION}

This study demonstrates the presence of functional KARs assembled with the GluR6 subunit in the dorsal striatum. KARs are found to modulate GABAergic synaptic transmission. We propose that this effect is, at least in part, indirectly mediated by the release of adenosine acting on $\mathrm{A}_{2 \mathrm{~A}}$ receptors.

\section{Functional GluR6-containing KARs in the dorsal striatum}

GluR6 mRNA and KA2 mRNA are present at a high level in the mouse or rat striatum, but not GluR5 or KA1, whereas GluR7 mRNA is present at low levels in only a subpopulation of striatal neurons (Bischoff et al., 1997). We further show that substance P-containing neurons (projecting directly to the substantia nigra) and enkephalin-containing neurons (projecting to the globus pallidus) both express GluR6 mRNA. These two populations of GABAergic neurons represent $>95 \%$ of neurons in the dorsal striatum (for review, see Gerfen, 1992). Thus, GluR6 is abundant in the majority of striatal neurons, in accordance with the ability of low concentrations of domoate to activate inward currents in most cells examined. Previous work had already demonstrated excitatory responses to low concentrations of kainate in rat striatal slices (Calabresi et al., 1990). In this study, we show that these excitatory responses to kainate and domoate are likely mediated by KARs and not AMPARs because they are not affected by the AMPA receptor antagonist GYKI 53655 as well as by low concentration of NBQX. In addition, in GluR6-deficient mice, no inward currents are activated by low concentrations of domoate, thus demonstrating that KARs in striatal neurons comprise the GluR6 subunit.

\section{EPSCs are not mediated by activation of KARs in} the striatum

EPSCs evoked by single pulse intrastriatal stimulations were largely inhibited by NBQX or GYKI 53655, but residual synaptic currents of small amplitude $(<10 \mathrm{pA})$ were observed. In the hippocampus and basolateral amygdala, high-frequency stimulation allowed the demonstration of slow KAR-mediated EPSCs and EPSPs (Castillo et al., 1997; Vignes and Collingridge, 1997; Li and Rogawski, 1998; Mulle et al., 1998). In the striatum, EPSCs evoked by single stimulation or a train stimulation were not blocked by increasing concentrations of NBQX or CNQX. Furthermore, these EPSCs were also observed in GluR6-deficient mice, whereas inward currents activated by bath application of domoate were completely blocked. These data argue against the participation of GluR6-containing KARs in the GYKI-resistant EPSCs. Identification of the neurotransmitter system involved in these small synaptic currents resistant to classical antagonists of AMPA, kainate, NMDA, and $\mathrm{GABA}_{\mathrm{A}}$ receptors is beyond the scope of this article.

\section{Modulation of GABAergic synaptic transmission by GluR6-containing KARs}

GluR6-containing KARs have two distinct effects on GABAergic synaptic transmission in the striatum. Activation of KARs transiently increases the frequency of spontaneous GABAergic IPSCs of small amplitude (on average, $40 \mathrm{pA}$ ). Anatomical studies have clearly identified two sources of GABAergic afferents to striatal projection neurons: axons from local interneurons, likely parvalbumin-containing interneurons, and axon collaterals from other GABAergic striatal projection neurons (Gerfen, 1992). Activation of KARs evokes in the great majority of striatal neurons of medium size an inward current leading to large depolarization of the membrane and to transient action potential firing. Given the anatomical features mentioned above, this likely results in an increase in the frequency of IPSCs in postsynaptic striatal neurons. The small amplitude of these sIPSCs is consistent with the finding that mutual inhibition among medium spiny neurons is weak (Jaeger et al., 1994). In contrast, GABAergic interneurons exert powerful control on the activity of projection neurons (Koos and Tepper, 1999). It is noteworthy that IPSCs recorded in the presence of domoate display a much smaller 
A

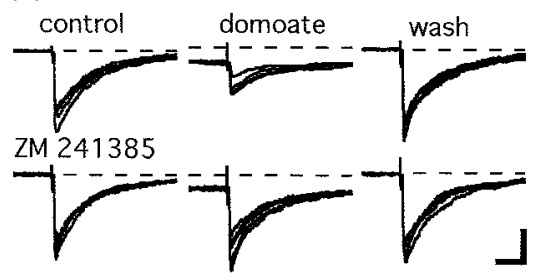

$\mathrm{B}$

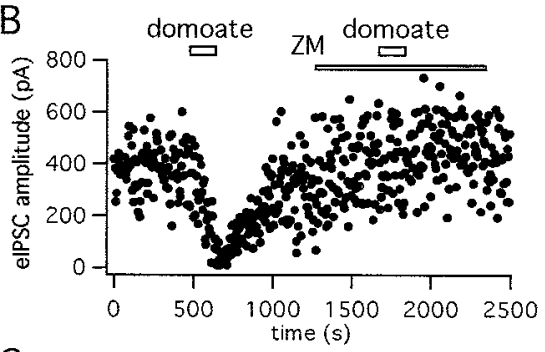

C

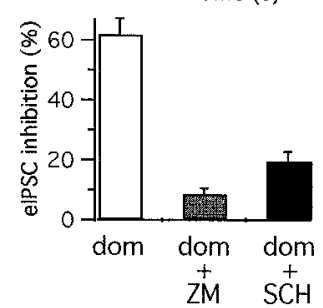

Figure 9. $\mathrm{A}_{2 \mathrm{~A}}$ receptor antagonists block the action of domoate on evoked IPSCs. $A$, IPSCs were evoked by intrastriatal stimulation (at a rate $0.2 \mathrm{~Hz})$ in the presence of NBQX $(1 \mu \mathrm{M})$. Top traces, Domoate $(500$ $\mathrm{nM}$ for $2 \mathrm{~min}$ ) reversibly decreased evoked IPSC amplitude. Bottom traces, In the same cell, perfusion of the slice with the selective $A_{2 A}$ antagonist ZM $241385(1 \mu \mathrm{M})$ prevented the action of domoate on evoked IPSC amplitude. The dotted line represents the level of the control inward current. $B$, For the same experiment, plot of the amplitude of evoked IPSCs as a function of time. Domoate is applied at the time indicated by the open horizontal bars. As indicated by the bottom horizontal bar, ZM $241385(1 \mu \mathrm{M})$ is perfused several minutes before the second application of domoate. $C$, Histogram of the average ( \pm SEM) inhibition by domoate (500 $\mathrm{nm}$ for $2 \mathrm{~min})$ of evoked IPSC amplitude in control conditions $(n=$ $18)$, in the presence of ZM $241385(1 \mu \mathrm{M})(n=7)$, and in the presence of SCH-58261 $(1 \mu \mathrm{M})(n=6)$. For both antagonists, the difference in inhibition versus domoate alone was significant with $p<0.001$.

amplitude than IPSCs evoked by minimal intrastriatal electrical stimulation. A likely interpretation is that IPSCs of small amplitude, whose activity is increased in the presence of a KAR agonist, are caused by the presynaptic activation of projection neurons, whereas large IPSCs evoked by intrastriatal stimulation are mainly caused by the stimulation of axons from GABAergic interneurons. Increase in sIPSCs of large amplitude is generally not observed in the presence of domoate, suggesting that low concentrations of domoate do not trigger spike discharge in GABAergic interneurons.

The second effect of KAR activation on GABAergic synaptic transmission is a large and prolonged decrease in the amplitude of IPSCs evoked by intrastriatal stimulation. In favor of a presynaptic mechanism, KAR activation moderately decreases the frequency of mIPSCs recorded in the presence of TTX. Interestingly, this decrease is mainly caused by a depression in the frequency of mIPSCs of larger amplitude. Decrease in mIPSC frequency is modest in comparison with the large decrease in eIPSC amplitude. An explanation for this discrepancy is that only a subclass of GABAergic synapses are affected by KAR activa- tion and that these synapses give rise to the large-amplitude eIPSCs.

In CA1 pyramidal cells of the hippocampus, activation of KARs also depresses evoked GABAergic synaptic transmission (Fisher and Alger, 1984; Clarke et al., 1997; Rodriguez-Moreno et al., 1997; Cossart et al., 1998; Frerking et al., 1998; Bureau et al., 1999). The exact mechanism of this downregulation and the subcellular localization of KARs involved is currently debated. This effect was attributed to a presynaptic action of KARs on GABA release (Rodriguez-Moreno et al., 1997). This proposal was based on the observation that kainate decreased mIPSC frequency and increased synaptic failures in CA1 pyramidal cells. However, using similar experimental procedures, several groups have failed to demonstrate a significant decrease in mIPSC frequency (Cossart et al., 1998; Frerking et al., 1998; Bureau et al., 1999) or a change in paired-pulse modulation (Frerking et al., 1998). Furthermore, a massive and long-lasting increase in sI PSC frequency was observed because of KAR-induced depolarization of presynaptic GABAergic interneurons. It has thus been suggested that this depression is mainly the consequence of somatic/ dendritic KARs in CA1 interneurons resulting in repetitive firing (Frerking et al., 1998).

The present study suggests another mechanism for the depressant role of KARs. KAR activation does depolarize presynaptic projection neurons and triggers action potential discharge. However, as mentioned above, the source of the large IPSCs evoked by intrastriatal stimulation is probably not caused by the stimulation of axons from projection neurons, but rather from GABAergic interneurons (Jaeger et al., 1994; Koos and Tepper, 1999). Domoate increases the frequency of sIPSCs of small amplitude but not of large amplitude, suggesting that KARs agonists do not trigger repetitive firing in GABAergic interneurons. The main argument in favor of a different mechanism is the finding that the effect of domoate could be an indirect consequence of the activation of KARs in striatal neurons. Indeed, we found that downregulation of eIPSCs by domoate was potently inhibited by the selective antagonists of adenosine $\mathrm{A}_{2 \mathrm{~A}}$ receptors, ZM241385 and SCH-58261. Pharmacological activation of $\mathrm{A}_{2 \mathrm{~A}}$ receptors with CGS-21680 moderately depresses eIPSC amplitude, as already reported in the rat (Mori et al., 1996), and prevents further inhibition by domoate likely by an occlusion mechanism. Glutamate plays an important role in stimulating the production and release of adenosine in the extracellular space in the striatum (Delaney et al., 1998). Adenosine is an important retrograde signal involved in the depressant action of dopamine and glutamate in synaptic transmission in the ventral striatum (Harvey and Lacey, 1997). The involvement of adenosine as a retrograde signal in the depression of synaptic transmission by kainate in the hippocampus was ruled out because an adenosine A1 receptor antagonist failed to block the inhibition of evoked IPSC and EPSC by kainate (Chittajallu et al., 1996). Adenosine also acts on $\mathrm{A}_{2 \mathrm{~A}}$ receptors that are mainly restricted to striatal areas (Svenningsson et al., 1997). The precise cellular and subcellular localization of $\mathrm{A}_{2 \mathrm{~A}}$ receptors involved in the downregulation of eIPSCs is at present unclear. Analysis of mIPSCs indicated that the depressant effect of $\mathrm{A}_{2 \mathrm{~A}}$ receptor activation was attributable to presynaptic but not postsynaptic $\mathrm{A}_{2 \mathrm{~A}}$ receptors (Mori et al., 1996; this study). In the rat, $\mathrm{A}_{2 \mathrm{~A}}$ receptors are expressed in striatopallidal projection neurons (Svenningsson et al., 1997). However, large-amplitude eIPSCs, which are affected by $A_{2 A}$ receptor activation, likely arise from axon collaterals of GABAergic interneurons and not from projection neurons (Jae- 
ger et al., 1994; Koos and Tepper, 1999). Data from Mori et al. (1996) and from this study thus suggest that $\mathrm{A}_{2 \mathrm{~A}}$ receptors are present on axon terminals from GABAergic interneurons that only represent a small population of neurons $(<4 \%)$ and could have been overlooked in in situ hybridization experiments.

The physiological conditions under which KARs are activated in the striatum remain to be determined. Our data suggest a possible role of GluR6-containing KARs in excitotoxicity in the striatum: activation of KARs not only depolarizes directly striatal neurons, but also increases excitability via disinhibition. This hypothesis is in line with the report of a genetic link between the GluR6 gene (GRIK2) and the age of onset of Huntington's chorea (Rubinsztein et al., 1997), a disease associated with a loss of projection neurons in the striatum (Beal, 1992; Feigin, 1998). GluR6-deficient mice will certainly prove useful to clearly assess the role of KARs in cell death in animal models of neurodegenerative diseases affecting the basal ganglia.

\section{REFERENCES}

Beal M (1992) Role of excitotoxicity in human neurological disease. Curr Opin Neurobiol 2:657-662.

Bettler B, Mulle C (1995) AMPA and kainate receptors. Neuropharmacology 34:123-139.

Bischoff S, Barhanin J, Bettler B, Mulle C, Heinemann S (1997) Spatial distribution of kainate receptor subunit mRNA in the mouse basal ganglia and ventral mesencephalon. J Comp Neurol 379:541-562.

Bleakman D, Lodge D (1998) Neuropharmacology of AMPA and kainate receptors. Neuropharmacology 37:1187-1204.

Bureau I, Bischoff S, Heinemann SF, Mulle C (1999) Kainate receptormediated responses in the CA1 field of wild-type and GluR6-deficient mice. J Neurosci 19:653-663.

Calabresi P, De Murtas M, Mercuri N, Bernardi G (1990) Kainic acid on neostriatal neurons intracellularly recorded in vitro: electrophysiological evidence for differential neuronal sensitivity. J Neurosci 10:3960-3969.

Castillo PE, Malenka RC, Nicoll RA (1997) Kainate receptors mediate a slow postsynaptic current in hippocampal CA3 neurons. Nature 388:182-186.

Chittajallu R, Vignes M, Dev KK, Barnes JM, Collingridge GL, Henley JM (1996) Regulation of glutamate release by presynaptic kainate receptors in the hippocampus. Nature 379:78-81.

Chittajalu R, Braithwaite S, Clarke V, Henley J (1999) Kainate receptors: subunits, synaptic localization and function. Trends Pharmacol Sci 20:26-35.

Clarke VR, Ballyk BA, Hoo KH, Mandelzys A, Pellizzari A, Bath CP, Thomas J, Sharpe EF, Davies CH, Ornstein PL, Schoepp DD, Kamboj RK, Collingridge GL, Lodge D, and Bleakman D (1997) A hippocampal GluR5 kainate receptor regulating inhibitory synaptic transmission. Nature 389:599-603.

Cossart R, Esclapez M, Hirsch J, Bernard C, Ben-Ari Y (1998) GluR5 kainate receptor activation in interneurons increases tonic inhibition of pyramidal cells. Nat Neurosci 1:470-478.

Delaney S, Shepel P, Geiger J (1998) Levels of endogenous adenosine in rat striatum. I - Regulation by ionotropic receptors, nitric oxide and free radicals. J Pharmacol Exp Ther 285:561-567.

DeVries SH, Schwartz EA (1999) Kainate receptors mediate synaptic transmission between cones and 'Off' bipolar cells in a mammalian retina. Nature 397:157-160.

Feigin A (1998) Advances in Huntington's disease: implications for experimental therapeutics. Curr Opin Neurol 11:357-362.

Fisher R, Alger B (1984) Electrophysiological mechanisms of kainic acid-induced epileptiform activity in the rat hippocampal slice. J Neurosci 4:1312-1323.

Frerking M, Malenka R, Nicoll R (1998) Synaptic activation of KARs on hippocampal interneurons. Nat Neurosci 1:479-486.

Gerfen C, Wilson C (1996) The basal ganglia. In: Handbook of chemical neuroanatomy (Swanson L, Bjorklund A, and Hökfelt T, eds), pp 371-468. Amsterdam: Elsevier.

Gerfen CR (1992) The neostriatal mosaic: multiple levels of compartmental organization in the basal ganglia. Annu Rev Neurosci $15: 285-320$.

Harvey J, Lacey MG (1997) A postsynaptic interaction between dopamine D1 and NMDA receptors promotes presynaptic inhibition in the rat nucleus accumbens via adenosine release. J Neurosci 17:5271-5280.

Jaeger D, Kita H, Wilson CJ (1994) Surround inhibition among projection neurons is weak or nonexistent in the rat neostriatum. J Neurophysiol 72:2555-2558.

Kamiya H, Ozawa S (1998) Kainate-receptor mediated inhibition of presynaptic $\mathrm{Ca} 2++$ influx and EPSP in area CA1 of the rat hippocampus. J Physiol (Lond) 509:833-846.

Kidd F, Isaac J (1999) Developmental and activity-dependent regulation of kainate receptors at thalamocortical synapses. Nature 400:569-573.

Koos T, Tepper J (1999) Inhibitory control of neostriatal projection neurons by GABAergic interneurons. Nat Neurosci 2:467-472.

Lerma J, Morales M, Vicente MA, Herreras O (1997) Glutamate receptors of the kainate type and synaptic transmission. Trends Neurosci 20:9-12.

Li H, Rogawski MA (1998) GluR5 kainate receptor mediated synaptic transmission in rat basolateral amygdala in vitro. Neuropharmacology 37:1279-1286.

Li P, Wilding TJ, Kim SJ, Calejesan AA, Huettner JE, Zhuo M (1999) Kainate-receptor-mediated sensory synaptic transmission in mammalian spinal cord. Nature 397:161-164.

Mori A, Shindou T, Ichimura M, Nonaka H, Kase H (1996) The role of adenosine A2a receptors in regulating GABAergic synaptic transmission in striatal medium spiny neurons. J Neurosci 16:605-611.

Mulle C, Andreas S, Pérez-Otaño I, Dickinson-Anson H, Castillo PE, Bureau I, Maron C, Gage FH, Mann JR, Bettler B, Heinemann SF (1998) Altered synaptic physiology and reduced susceptibility to kainate induced seizures in GluR6-deficient mice. Nature 392:601-604.

Paternain A, Morales M, Lerma J (1995) Selective antagonism of AMPA receptor unmasks kainate receptor-mediated responses in hippocampal neurons. Neuron 14:185-189.

Poucher S, Keddie J, Singh P, Stoggall S, Caulkett P, Jones G, Coll M (1995) The in vitro pharmacology of ZM 241385, a potent, nonxanthine A2a selective adenosine receptor antagonist. Br J Pharmacol 115:1096-1102.

Rodriguez-Moreno A, Lerma J (1998) Kainate receptor modulation of GABA release involves a metabotropic function. Neuron 20:1211-1218.

Rodriguez-Moreno A, Herreras O, Lerma J (1997) Kainate receptors presynaptically downregulate GABAergic inhibition in the rat hippocampus. Neuron 19:893-901.

Rubinsztein DC, Leggo J, Chiano M, Dodge A, Norbury G, Rosser E, Craufurd D (1997) Genotypes at the GluR6 kainate receptor locus are associated with variation in the age of onset of Huntington disease. Proc Natl Acad Sci USA 94:3872-3876.

Svenningsson P, Le Moine C, Kull B, Sunahara R, Bloch B, Fredholm BB (1997) Cellular expression of adenosine A2A receptor messenger RNA in the rat central nervous system with special reference to dopamine innervated areas. Neuroscience 80:1171-1185.

Vignes M, Collingridge GL (1997) The synaptic activation of kainate receptors. Nature 388:179-182.

Zocchi C, Ongini E, Conti A, Monopoli A, Negretti A, Baraldi PG, Dionisotti S (1996) The non-xanthine heterocyclic compound $\mathrm{SCH}$ 58261 is a new potent and selective A2a adenosine receptor antagonist. J Pharmacol Exp Ther 276:398-404. 